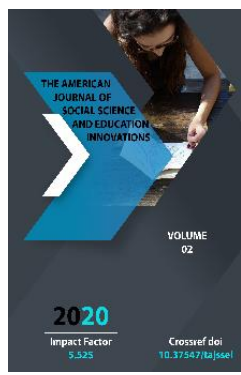

\title{
Scientific Heritage Of Muhammad Tarablusi
}

\author{
Mamadaliyev Nusratullo Saydazimovich \\ Student Of Master's Degree, International Islamic Academy Of Uzbekistan, Tashkent, \\ Uzbekistan
}

Copyright: Original content from this work may be used under the terms of the creative commons attributes 4.0 licence.

\section{ABSTRACT}

This article discusses the scientific legacy of the encyclopedic scholar Muhammad Tarablusi. The scientific heritage of Tarablusi includes the science of the Qur'an and hadith, mysticism and tafsir. It is important to analyze his scientific work and translate it into Uzbek. Because it is our duty to pass on such a scientific heritage to future generations.

\section{KEYWORDS}

Muhammad Tarablusi, Qur'an, hadith, tafsir, mysticism

\section{INTRODUCTION}

The full name of the scholar is Muhammad ibn Khalil ibn Ibrahim ibn Muhammad Tarablusi (1809-1888) who is known for his multifaceted scientific work, and it can be seen that his works are not limited to a certain part of the religious field but cover all the main fields. This is because the scholar was educated by mature teachers in every field of his time. Among them are the famous scholar Sheikh Ibrahim Bojuli, Sheikh Muhammad ibn Ahmad Khalili Tamimi (Mufti of the Hanafi school in Egypt), Sheikh Muhammad ibn Ahmad ibn Yusuf Bahi Misri, Sheikh Muhammad Obid ibn Ahmad Salih Ansari Sanadi, Sheikh Muhammad Salih Siboi Adavi, Sheikh Ahmad Saidi Maliki et al. 


\section{MAIN RESULTS AND FINDINGS}

Can it be concluded that the scholar's scientific heritage is extensive, he also reached the level of an encyclopedic scholar in his time in Islamic sciences such as Ghazali, Tahanavi, Mullah Ali Qari, Imam Nawawi.

The following is a brief account of the scientific legacy of Muhammad Tarablusi.

"Rabi ul-Jinan fi Tafsir al-Qur'an" is a work devoted to the interpretation of the verses of the Qur'an, which reflects the scholar's scientific position in his time. After all, not all scholars who have written many works have dared to interpret Kalamullah. Only mature scholars who have acquired deep knowledge and gained the trust of their teachers are considered to have embarked on this work.

"Masarrotul aynayn ala tafsiril jalalayn" consists of the author's comments and remarks on "Tafsir al-jalalayn", a commentary on the Qur'an that is popular in the Hanafi School.

It is known that "Jalalayn's Commentary" is a masterpiece in the world of commentary due to its extreme conciseness, ie the fact that the commentaries do not exceed the size of the text of the verses. Scientific Tarablusi, also known as "The Joy of the Eyes Dedicated to the Interpretation of Jalalayn," deserves special attention in the future.

"Jamalur raqs fi qurroi hafs" is about the reciters of the Qur'an, which came with the series of Imam Hafs, which shows how well the author is aware of the science of Tajweed, in particular, the science of rijal in relation to the narrations of the reciters.
The work "Ruhul bayan fi khovassin naboti val hayavon" is about the peculiarities of the flora and fauna, and shows that the scientist has a good grasp of secular knowledge and environmental sciences.

"Al-jomeul fayyoh li javomeil kutubis sihoh" is a major book of hadith commentary on a collection of authentic hadiths. In this play, the author writes a commentary on all of them, without distinguishing the hadith scholars who are the owners of authentic collections. In his other works, the author has also written about a particular collection or author.

One such work is "Tashilul Masolik Mukhtasaru Muwattai Malik", which is dedicated to Muwatta, the most famous work of Imam Malik ibn Anas.

"Az-Zahabul Ibriz alal Mujamil Vajiz" can be called an explanatory dictionary of the Arabic language. The Arabic language is rich in words, and great books have already been written that can hold several hundred thousand words. The most famous of these is Ibn Manzur's "Lisonul Arab". But such short books have always been written in accordance with the requirements of the time. This work was carried out by scholars who had a deep knowledge of the language at different times. This work was published in hijrah 1310 in Beirut [12].

"Al-Badrul Munir Mukhtasarul Jomeus Saghir" is a commentary on Al-Jomeus Saghir, one of the six books on which the Hanafi school is based.

"Al-lu'lu'ul marsu' fil hadith" subject is one of the most topical issues in hadith studies. The author points out that thousands of hadiths narrated from the Messenger of Allah (peace and blessings of Allah be upon him) are 
circulating among the people, including some of the works of some neglected authors. Of course, special knowledge and skills are needed to distinguish fabricated hadiths from authentic hadiths. This work is as subtle as it is important in studying and practicing pure Islam.

The next work is the book "Tanvir al-Qulubi wa'l-absor wa nuzhatul uyuni wa'l-afkar fi ahadithin nabiyyil mukhtar," which is a collection of hadiths from the Messenger of Allah (peace and blessings of Allah be upon him). The title of the work can be summarized as "enlightening the hearts and eyes on the subject of the hadiths of the chosen prophet." "Al-fathul mubin alal hisnil hasin" (meaning an open conquest of the fortress of the seeker) is about prayers and dhikr, and given that it is a supplication to avoid various calamities, most of these works are usually used with words such as "hisn" or will be called "fortress".

It is well known that hadith scholars not only write commentaries on major authentic books, but also write about other collections of hadith that are popular in the Islamic world. One of the most famous works of hadith commentators is the work of Imam al-Nawawi "Arbayn", which contains forty hadiths.

The scholar Muhammad Tarablusi also wrote a work entitled "Al-Imdadotul ilahiyya alal arbaiynin nawawiyya" in which he commented on forty hadiths of Nawawi.

As can be seen from its content, "Raf'ul astaril musdala fil ahadisil musalsala" (raising the curtains about the hadiths of the series) is dedicated to opening the "veil of abstraction" in some hadiths by introducing people who are abstract in the series of documents. Of course, the importance of the works in this category is no less than that of the other works devoted to the science of hadith mentioned above. This is because in order to follow the hadiths of the Prophet, it is important not only to understand the content of the hadith, but also the reliability of the narrators who narrated that hadith, and how well-known their personalities are.

"Latoifur rojiyn va bugyatut talibiyn fi usulil muhaddisiyn va qovaidid diyn" (anecdotal information about the rules of religion and the method of muhaddithin that students want) provides information about the methods of muhaddithin to extract the basics of religion.

Called "Safinatun najah fi marifatillah" (the ship of salvation in the knowledge of Allah), this work contains pandu advice related to the training of the heart and soul, such as piety, austerity, sincerity, which directs the heart of the servant to the knowledge of Allah. Of course, to write such a work, the author must have sufficient mystical knowledge and skills. This work was published in hijrah 1322 [12].

"Gunyatut Talibin fima yajib min ahkamid din alal mazahibil arba'i" is a work on the jurisprudence of the four sects, which provides evidence of the issues that the student needs to know in each sect.

This work, entitled "Yanbu'ul hayat ala safinatin najat" (the fountain of life on the ship of salvation), is also a moral and educational work.

"Inoyatul Muhtadi Ala Kifayatil Mubtadi" is a commentary on the Hanafi School. The book "Kifayat al-Mubtadi" based on reliable sources on the Hanafi school, has been commented on by many scholars.

As can be seen from the title of the work "Tuhfatun nasik fil manasik" (a gift to the monument about prayers), for the worshipers 
and ascetics, it includes systematic tasks about prayers, pilgrimage arches, as well as prayers and virdas.

The work "Ad-durrus sofi ala aqidatin nasafiy" proves that the famous scholar Abu Omar Nasafi was not left out of Tarablusi's attention. In this work, the author comments on Nasafi's work on the science of aqeedah. The title of the work is "Pure Stand Dedicated to the Nasafi Belief."

This work, entitled "Vuzu'ul manazil fima varoda minan navafil" (enlightenment of houses about supererogatory prayers), describes the virtues of supererogatory prayers in addition to the obligatory prayers.

The work "Kavkabut tarsif fima lil hanafiyyati minat tasnif" contains the authors of the works of fiqh of the Hanafi school and the classification of their works.

"Al-Maqasidus Sunniyya fi Adabis Sufiyya" (Sunni Objectives in Sufi Etiquette) is about mysticism, specifically discussing two different issues that revolve around mystics. One is to prove with evidence that some of the dhikrs and deeds that seem to be abstract and unfounded are among the deeds of the mystics to whom the chain of the Prophet (peace and blessings of Allah be upon him) is based. Sufis are called upon to bring their actions into line with the Sunnah and to carry out each action in a reasonable manner.

The work entitled "Qovaidut tahqiq fi usuli ahlit tariq" (Rules of research on the Ahl al-Tariq method) is similar in content to the work above. Only, as can be seen from the difference in its title, if the above work is a study of mystics, this work is a guide for those who want to do research on them.
"Rayhonatul qulub fi holvatil mahbub" (Rayhan of hearts about the solitude of the beloved) is about the knowledge of Allah and the creation of enlightenment. Obviously, writing a work on these topics shows the level of the author. Scholars can complete works in many fields, but not only knowledge and skills are enough to write a book about the enlightenment of Allah, but the scholar himself must have reached a sufficient level. Of course, a scientist does not make such a claim about himself, but his actions and works testify to it.

"Nasimush shajiyyil awwah fi fazli laa ilaha illallah" is also close to the heart of the work. In it, he spoke about the phase of the word tawhid, the responsibility of the Muslim who carries it.

This work entitled "Al-fizzatun naqiyya $\mathrm{fi}$ sulukit tariqil holvatiyya" (pure silver on the path of the sect of solitude), is also about the sect. It calls for the actions of the "mystics", which consist of a dry claim, to be in accordance with the Sunnah, and for each action to be carried out in a reasonable manner.

"Al-barqatud dahshiyya fi lubsi hirqatis sufiyya" (a bright flash of light on wearing the Sufi hijab) is also close in content to the mystical works mentioned above.

The author has written "Hadith al-Ahbab" (a gift to loved ones) as an admonition to his brothers and sisters, and on the basis of the saying, "A believer cannot give his brother anything better than admonition", this pandnoma is a gift to anyone who wants that can do to share goodness.

The next work is similar, but because it contains specific recommendations, it is called "Wasiyatul ihwan val ashob" - "testament to brothers and friends." 
The work "Miftahul kanzil afhor liman aroda an yasila ilal ginal akbar" (the key to the greatest treasure for those who want to achieve the greatest wealth) is not about material wealth and riches, but to show its way to those who want to enter Paradise is a pamphlet to direct them to prayers and righteous deeds. This work is also essentially a partner of the two works listed above. This work was published in Cairo in hijrah 1294 [12].

This work, entitled "Nuzhatul arvoh fi asrorin nikah" (The Journey of Spirits on the Secrets of Marriage), contains reflections on marriage, one of the most important stops in human life, and its wisdom and mystery. The purpose of introducing marriage is to provide important information about the blessings promised for family life through it, such as marriage as one of the ways of getting rich that the Shari'ah recommends.

This work, entitled "Sharhun alal kofi fi ilmayil aruz val qawafi" (commentary on the work of qofiyya on the science of aruz and rhyme), is radically different from the above. The reason is that this work is about the weight of literature and rhymes, which shows that the author has a thorough knowledge of Arabic literature. By the way, it is no coincidence that Dr. Khalid Barish, who wrote about Tarablusi in his article, also called him a poet.

One of the indications of the status of the Arabic language over other languages is that those who specialize in the social sciences and humanities in the Arab world are well versed in the Arabic language, its literature and its genres. You will not find such a situation in other languages.

In this work, called "Ma'danul la'ali fil asanidil avaliy" (the mine of jewels about higher documents), the author is engaged in the introduction of the rings in the chain of hadith and other sciences in the system of teachers and students, the study of their identity.

In "Al-Bahjatul Qudsiyya fil Ansabin Nabawiyya", the scholar wrote about the Nabawi lineage, that is, the genealogies that reach the Prophet (peace and blessings of Allah be upon him).

This work, entitled "Vasilatul Maksud ilar Robbil Ma'bud" (The Guardian of the Purpose of Dealing with God), is a pamphlet aimed at showing the way of productive remembrance to the worshipers, directing them to more serious prayers and righteous deeds.

This work, entitled "Mawahibur Rahman fi Khosaisil Qur'an", is about the Qur'an, first, about its revelation as a guide to the worlds, the events that led to its revelation, and their wisdom. Aimed at explaining that. Then, the suras that are part of it contain information about their phase, content, and the feature that distinguishes each surah from the others. It is also emphasized that there is good news for those who constantly read and memorize the Qur'an, study its content, and apply it to their lives.

Of course, it is not an exaggeration to say that a scholar who interprets the Qur'an, as well as writes a work on the sciences of recitation and tajweed, as mentioned above, reads the Qur'an and writes a work of good news for those who follow it.

\section{CONCLUSION}

Muhammad Tarablusi was one of the most mature representatives of his time, whose knowledge was not limited to one direction, but left a mark on his disciples from almost all of the Islamic sciences. In an article published in Beirut three years ago about the period in 
which he lived, Dr. Khalid Barish explained that many murids would gather at the mosque to listen to his teachings and receive continuous education for years. In those days, this method of education was not considered inferior to the university level in the period when formal universities had not yet been established. The reason is that the seeker of sciences listened to lectures not only on one subject or one subject, but on all the necessary subjects from different disciplines. Listening to such a lecture was completely different from listening to a Friday sermon as it is today. Student attendance was continuous, recording the lessons they had heard and checking with the teachers. Those who wanted to be educated in a more specific way attended the teachers 'homes.

Of course, Muhammad Tarablusi worked tirelessly from a young age to gain such fame in such a competitive environment. He had a scientific environment in the family in which he grew up. Growing up in such an environment, this worthy scholar left behind many future students and works that will be a program for them.

\section{REFERENCES}

1. Sheikh Muhammad Sadiq Muhammad Yusuf. (2011) Sunni beliefs. Tashkent: Publishing and Printing Joint-Stock Company "SHARQ" General Editorial Office. p 544.

2. Sheikh Muhammad Sadiq Muhammad Yusuf. (2013) Aqeedah science and related issues. Tashkent: HILOL-NASHR Publishing House. P 352.

3. Sheikh Abdulaziz Mansur. (2006) Aqoid texts. Tashkent Islamic University Publishing and Printing Association.

4. Abu Mansur Moturidi. (2004) Ahl al-Sunnah. - Beirut: "Muassasatur risalati nashiruna".
5. Abu Mansur Moturidi. (2006) The Book of Tawheed. Beirut: "Dorul kutubil ilmiya".

6. Ziyodov Sh. (2003) Abu Mansur al-Moturidi and his role in the development of the Mawarounnahr school of kalam: thesis. Tashkent: Uz ASIO. P 67.

7. Nuruddin Sobuniy. (1995) Bidoyatu fi usulid din. - Ankara: "Ankara".

8. Muhammad Tarablusiy. (1996) MukhtasaruI-itimod fi-l-itikod. Beirut.

9. Ziyovuddinova M. (2001) Arabic literature. Tashkent.

10. Xodjaeva R. U. (2004) New Age Arabic Literature. Tashkent.

11. Sulaymonova F. (1997) East and West. Tashkent.

12. Inshah newspaper, issue 12.05.2017. Dr. Khalid Barish's article "Al-Arif billah Abul Mahosin Kovukji". Beirut. 2017. 